ANDRZEJ WielońsKi

Uniwersytet Warszawski

\title{
Renesans polskiego hutnictwa żelaza i stali
}

Hutnictwo żelaza i stali korzysta wyłącznie z rud żelaza i koncentratów importowanych głównie z Ukrainy i Rosji. Również importowane są metale uszlachetniające stal: mangan, chrom i tytan, oraz część złomu, którego zużycie zwiększyło się w ostatnich trzech latach z 3600 tys. ton do 6200 tys. ton. Duża głębokość zalegania $(800-2300$ m) i unikatowe wartości przyrodnicze regionu (sąsiedztwo Wigierskiego Parku Narodowego) wykluczają eksploatację odkrytych w 1962 r. na północ od Suwałk złóż rud magnetytowo-ilmenitowych $\mathrm{z}$ domieszką wanadu.

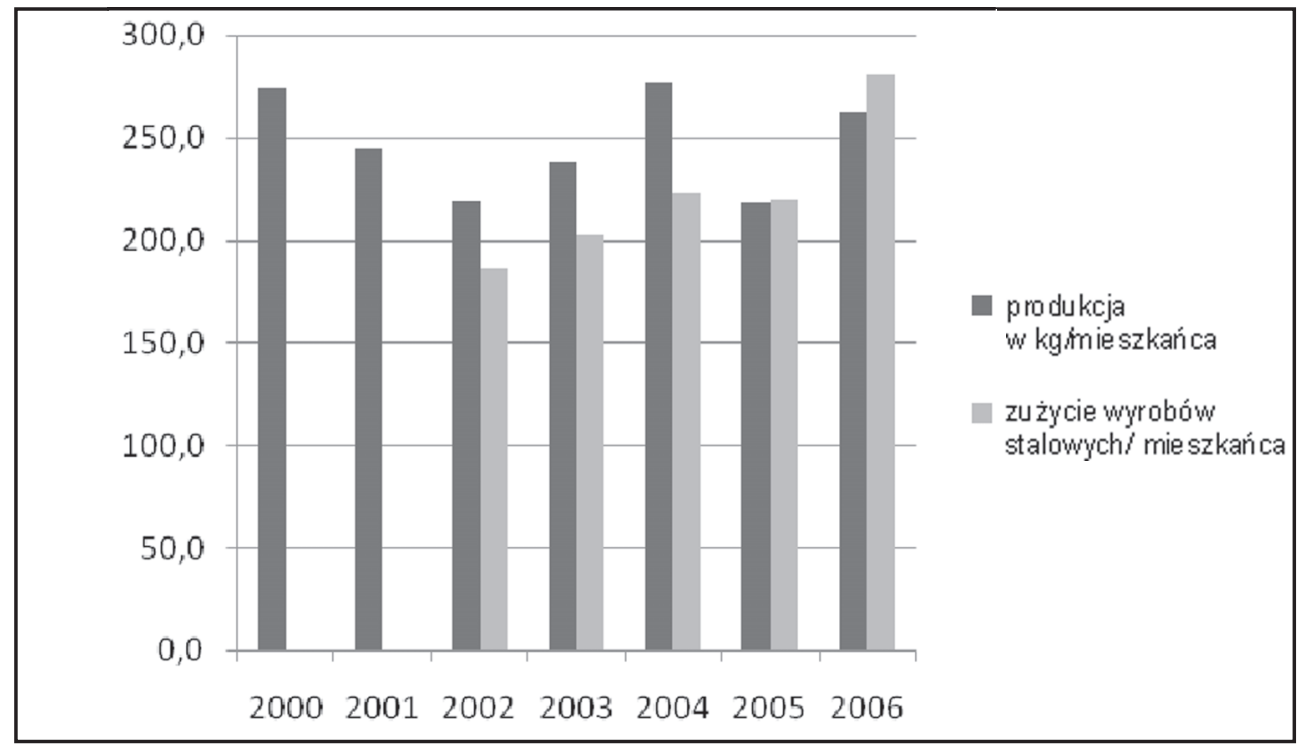

Ryc. 1. Produkcja i zużycie stali

*w 2000 i 2001 brak danych dotyczących zużycia wyrobów stalowych na 1 mieszkańca 
W 2006 r. wyprodukowano 9981 tys. ton stali ${ }^{1}$. Udział stali wytopionej w procesie konwertorowym stanowił $58 \%$, natomiast w procesie elektrycznym $-42 \%{ }^{2}$. W strukturze produkcji dominowała stal niestopowa; stal stopowa stanowiła $5 \%$ produkcji, w tym stal odporna na korozję $0,07 \%$.

Większość hut zlokalizowana jest na Górnym Śląsku oraz w jego sąsiedztwie. Ośrodkami hutnictwa są: Dąbrowa Górnicza, Sosnowiec, Świętochłowice, Chorzów, Gliwice, Siemianowice Śląskie, Łaziska Górne, Ruda Śląska, Zabrze, Kraków, Bochnia, Częstochowa, Zawiercie oraz Ozimek i Zawadzkie nad Małą Panwią. Dla części z nich określenie huta ma znaczenie wyłącznie historyczne, gdyż współcześnie są to przedsiębiorstwa przetwórstwa hutniczego specjalizujące się w produkcji rur stalowych (Huta Batory - Chorzów, WRJ Serwis-d.Huta Jedność - Siemianowice Śląskie, Walcownia Rur Andrzej-d.Huta Andrzej Zawadzkie), blach transformatorowych i ochronnych barier drogowych (Stalprodukt - d.wydziały produkcyjne huty w Krakowie - Bochnia), akcesoriów kolejowych i górniczych (Huta Królewska - Chorzów), obręczy kolejowych i tramwajowych do zestawów kołowych (Huta Bankowa - Dąbrowa Górnicza) oraz obudów chodników i akcesoriów górniczych (Huta Łabędy - Gliwice).

1 stycznia 2003 r. Huta Katowice w Dąbrowie Górniczej - największy krajowy producent wyrobów długich, w tym zwłaszcza szyn, Huta im. T. Sendzimira w Krakowie - największy krajowy producent wyrobów płaskich, w tym zwłaszcza blach i taśm, Huta Cedler w Sosnowcu i Huta Florian w Świętochłowicach weszły w skład utworzonego koncernu Polskie Huty Stali, stanowiącego wzorem największych światowych producentów pełny ciag technologiczny. Pod koniec 2003 r. zagranicznym inwestorem w Polskich Hutach Stali (obecnie Arcelor Mittal Steel) został Mittal Steel, który kupił również największą polską koksownię w Zdzieszowicach ${ }^{3}$. Jednym z warunków sprzedaży było zobowiązanie się inwestora do budowy nowych lub modernizacji istniejących linii produkcyjnych wyrobów płaskich we wszystkich czterech hutach. Huty w Krakowie, Dąbrowie Górniczej, Świętochłowicach i Sosnowcu skupiają 70\% potencjału krajowego hutnictwa i wytwarzając 7,6 mln ton stali, 6,6 mln ton wyrobów walcowanych i 6 mln ton koksu ${ }^{4}$ (2006 r.).

W 2003 r. inwestora zagranicznego pozyskała również huta w Zawierciu (CMC) oraz kontynuująca stare tradycje hutnictwa w Staropolskim Okręgu Przemysłowym huta w Ostrowcu Świętokrzyskim (Celsa), natomiast w 2005 r. - huta w Częstochowie (ISD) specjalizująca się w produkcji blach grubych dla przemysłu stoczniowego.

Tradycje hutnictwa, sięgające budowy w okresie międzywojennym Centralnego Okręgu Przemysłowego, kontynuuje Huta Stalowa Wola - producent stali jakościowych, maszyn budowlanych do prac ziemnych i drogowych (ładowarki kołowe, spycharki gąsienicowe, układarki rur, koparko-ładowarki) oraz sprzętu wojskowego (transportery opancerzone, sprzęt artyleryjski, sprzęt inżynieryjny). Producentem stali jakościowych (m.in. sprężynowej, łożyskowej, śrubowej) jest również huta w Warszawie (Arcelor Mittal). Zlokalizowana

${ }^{1}$ W 2006 r., głównie za sprawą Chin, światowa produkcja stali przekroczyła $1200 \mathrm{mln}$ ton.

${ }^{2}$ Zmniejszenie produkcji stali w latach 90 . XX w. (w 1980 r. - 19000 tys. ton), towarzyszące zapoczątkowanej w 1992 r. restrukturyzacji hutnictwa, odbywało się głównie na skutek ograniczania wytopu w przestarzałym procesie martenowskim.

${ }^{3}$ Sprzedaż Polskich Hut Stali budzi nadal kontrowersje. Wątpliwości przeciwników sprzedaży dotyczą głównie ceny; zwolennicy przypominają, że podpisując umowę prywatyzacyjną inwestor musiał spłacić 5 mld zł zadłużenia.

${ }^{4}$ Oprócz koksowni w Zdzieszowicach koks wytwarzany jest również w hucie w Krakowie. 
w największej odległości od Górnego Śląska, dysponująca własnym portem przeładunkowym Huta Szczecin produkuje wyłącznie wielkopiecową odlewniczą surówkę żelaza 5 .

W 2006 r. przemysł stalowy dostarczył 7682 tys. ton wyrobów walcowanych na gorąco, 1577 tys. ton wyrobów zimnego przetwórstwa (blachy i taśmy ocynkowane na zimno, blachy i taśmy ocynkowane, blachy i taśmy z powłokami organicznymi), 423,3 tys. ton rur (bez szwu i ze szwem) oraz 373,1 tys. ton kształtowników giętych na zimno zamkniętych. Strukturę produkcji wyrobów walcowanych na gorąco charakteryzuje zdecydowanie większy udział wyrobów długich (walcówka, pręty, kształtowniki ciężkie, kształtowniki lekkie, szyny) - 62\%, niż płaskich (blachy taśmowe, blachy grube) $-38 \%$.

Krajowe zużycie wyrobów stalowych, które w latach 2003-2005 ustabilizowało się na poziomie ok. 8000 tys. ton, w 2006 r. zwiększyło się do 10665 tys. ton. Przyczynił się do tego głównie wzrost zużycia wyrobów płaskich z 3190 tys. ton w 2002 r. do 5491 tys. ton w 2006 r. W strukturze zużycia wyrobów stalowych przeważa zużycie wyrobów płaskich $-51 \%$, wyroby długie stanowią 39\%, rury i kształtowniki gięte na zimno zamknięte $-10 \%$.

Niedostosowanie struktury produkcji (przewaga wyrobów długich) do struktury zużycia (przewaga wyrobów płaskich) powoduje, że udział importu w krajowym zużyciu wyrobów stalowych od 2005 r. przekracza 50\%, natomiast bilans handlu zagranicznego wyrobami stalowymi jest ujemny. W strukturze importu znaczący udział mają wyroby płaskie $-60,3 \%$, natomiast w strukturze eksportu wyroby długie $-51,3 \%$ oraz wlewki i półwyroby $-24 \%$.

Sytuacja ulegnie zmianie po zakończeniu dwu inwestycji w hucie w Krakowie. Pierwsza, ukończoną w sierpniu 2007 r., jest nowa walcownia gorąca blach o zdolności produkcyjnej 2400 tys. ton, druga - modernizacja i rozbudowa istniejącej walcowni zimnej blach o zdolności produkcyjnej 800 tys. ton do 2000 tys. ton. Dzięki tym inwestycjom będzie możliwa produkcja pełnego asortymentu blach dla potrzeb producentów samochodów i sprzętu AGD.

Restrukturyzacji techniczno-technologicznej hutnictwa żelaza i stali towarzyszyła restrukturyzacja zatrudnienia. Liczba zatrudnionych zmniejszyła się w latach 1989-2006 o ponad 100 tys. Łagodzeniu społecznych konsekwencji restrukturyzacji zatrudnienia służyły Hutniczy Pakiet Socjalny i Hutniczy Pakiet Aktywizujący.

Efektem restrukturyzacji hutnictwa żelaza i stali przeprowadzonej z udziałem zagranicznych inwestorów jest wzrost produktywności pracy (wydajności) mierzonej produkcją stali na jednego zatrudnionego. W latach 2003-2006 zwiększyła się ona z 222 ton do 321 ton (Unia Europejska 15-500 ton).

Kolejne lata przyniosą dalszy wzrost zapotrzebowania na stal spowodowany realizacją inwestycji finansowanych z funduszy Unii Europejskiej oraz inwestycji związanych z organizacją Euro 2012. Zagrożenie dla produkcji stwarza decyzja Komisji Europejskiej zmniejszająca zaproponowany przez Polskę limit emisji $\mathrm{CO}_{2} \mathrm{w}$ latach 2008-2012 z 284,6 mln ton do 208,5 mln ton.

\section{Renaissance Polish Steel Industry}

In 2006 Poland's steel makers produced steel makers produced about $10 \mathrm{M}$ mt crude steel (in $2002-8,4 \mathrm{M} \mathrm{mt}$ ); consumption in 2006 was $10,7 \mathrm{~m} \mathrm{mt}$ (in $2002-7,1 \mathrm{M} \mathrm{mt}$ ). Flat products prevailed within domestic consumption of steel (51\% of total consumption). Imports to consumption were $50 \%$. Higher steel consumption was mainly driven by Polish economy growing fast, absorption of EU structural funds into growth0boosting and new projects.

${ }^{5}$ Tradycje hutnictwa w Szczecinie sięgają przełomu XIX i XX w. 